\title{
VITA
}

\section{A TÁRSADALOMFÖLDRAJZ ÉS A REGIONÁLIS TUDOMÁNY}

\author{
(Hozzászólás Probáld Ferenc cikkéhez)
}

\section{ENYEDI GYÖRGY}

Gondolatébresztő, szép stílusú dolgozatot írt Probáld professzor a társadalomföldrajz és a regionális tudomány viszonyáról. Szükséges a kutatásaink mögött álló elméletek újrafogalmazása, mivel ezek az elméleti keretek s tartalmak változnak, ahogyan a kutatás tárgya is változik, módszereink finomodnak, a kutatási tapasztalatok visszacsatolása is módosítja az elméleti megfontolásokat. Az eredményes kutatás első feltétele, hogy a kutatási hipotézis elméletileg megalapozott $\mathrm{s}$ világosan megfogalmazott legyen. Különösen időszerü az általunk müvelt diszciplina újragondolása, midőn a hagyományosan intézményesült diszciplinák egyidejüleg szét-tagolódnak, belülröl specializálódnak és integrálódnak, más diszciplinákkal fonódnak össze.

A szerző a társadalomföldrajz és a regionális tudomány definicióinak fejlödéstörténeti vizsgálatából arra a következtetésre jut, hogy ,az önálló regionális tudomány létrejötte nem tekinthetô szükségszerünek, tudományrendszertanilag indokoltnak". Magyarán: a regionális tudomány feladatkörét, vizsgálati céljait, módszereit a társadalomföldrajz is magáénak tekintheti, csak véletleneken múlott, hogy, mintegy megkettỏződve, egymás konkurensei lettek. Pedig: a geográfia önálló diszciplina jellegéhez kétség sem férhet, míg a regionális tudomány mibenléte igencsak vitatott.

Úgy vélem, nagyrabecsült barátom több dologban téved, vagy tévesen egyszerüsít. Az elsö tévedés szerintem az, hogy az „egyértelmű definícióval” bíró társadalomföldrajzot (human geography) veti egybe a zavaros, ellentmondásos s vitatott elméleti alapú regionális tudománnyal. Nos, a társadalomföldrajznak is többféle definiciója van, s nem merném angolul human geography-nak nevezni, mert akkor nincs szavam a social geography számára... Egyébként: ha lefordítjuk magyarra a social geography, géographie sociale vagy a Sozialgeographie (angol, francia, német) tudomány rendszertani megnevezéseket, „társadalomföldrajz” az eredmény, pedig belső tartalmuk igencsak eltér egymástól. A német Sozialgeographie, például, a „társadalomtudományi szemléletü funkcionális emberföldrajz irányzata, a kulturgeográfia rész-diszciplinája, a ... különbözö társadalmi csoportok létfunkcióival (társadalmi alapfunkcióival ) összefüggő térképző folyamatok és területi szervezeti formák tudománya" - irja eme irányzat kitünö hazai ismerője s követỏje, Berényi 
István (Berényi 2004, 10). Ez nem sok hasonlóságot mutat a szerző által idézett definiciókkal. Az már külön magyar sajátosság, hogy az elmúlt két évtizedben tartalmi változás nélkül átneveztek gazdasági földrajzi tanszékeket, s hagyományos gazdasági földrajzi kézikönyvek kaptak társadalom-földrajzi címet.

A különböző definíciókat egybevetve szembetünő, hogy a társadalom térbeli folyamatait a geográfia - természetesen - a természeti környezettel való kapcsolatában is vizsgálja; a regionális tudomány, a telephely-elméletböl kifejlődve, elméleti térmodelljeiben mindig eltekintett a természeti földrajzi környezet hatásaitól. E modellek homogén terek (Thünentöl Weber-en, Christaller-en, Lösch-ön, Boudeville-en át Isard-ig), hogy a költség-távolság hatásai, a szállitási hálózaton belüli fekvés hatása stb. kimutathatók, cél-függvénybe fogalmazhatóak legyenek.

Egy másik - apró - pontatlanság, hogy a szerző a regionális tudomány hazai intézményesülését az 1980-as évekre (az „Isard utáni” időszakra) teszi. Az MTA Regionális Kutatások Központja, a regionális tudomány elébb poszt-graduális, majd graduális oktatása valóban ez időben alakult, ám a Regional Sciences Association (RSA) Magyar Nemzeti Bizottságának megalakulása az 1960-as évek végén (mely bizottság a hetvenes években kétszer is Budapestre tudta hozni az RSA európai kongresszusát), még korábban a Marx Károly Közgazdaságtudományi Egyetem területi tervező szak-képzése is egyfajta intézményesülés volt.

A harmadik ellenvetésem, hogy a társadalomföldrajz és a regionális tudomány "felcserélhetőségét" nem bizonyíthatjuk a kutatási témák hasonlóságával. Egy-egy kutatási témát több diszciplina is vizsgálhat, ám szempontjaik, módszereik, célfogalmazásuk igencsak eltérő lehet. Például, a települések területi egyenlőtlenségeit a társadalomföldrajz, a településtudomány/urbanisztika, a település-szociológia, a településtörténelem, a közigazgatás-tudomány, a közgazdaságtan, a környezettudomány a maga szempontjai szerint vizsgálja, hol a városi gazdaság, a helyi társadalom, hol a település-kormányzás (governance) s még egy sor más szempontból; hol a tudományos leírás, hol a tipológia, hol az egyenlőtlenségeket korrigáló településpolitika megfogalmazása s még egy sor cél érdekében, különböző módszereket alkalmazva. Ezek a diszciplinák a települések térbeli egyenlőtlenségeit kialakító hosszú távú gazdasági-társadalmi mechanizmusnak csak egy-egy elemét vizsgálják. A geográfia tér-szintézise nem tartalmazza az egyes elemek rész-mechanizmusainak feltárását, a település-szociológia a települési egyenlőtlenségeket a társadalmi egyenlőtlenségek vizsgálatába illeszti, stb. A regionális tudomány kísérli meg a teljes körü szintézist. Nem mintha szuper-tudomány lenne, csak sajátos: a térfolyamatok egyes diszciplinák által tanulmányozott mechanizmusait, törvényszerüségeit, modelljeit olvasztja egy meta-szintézisbe. Nem egyedülálló: integratív diszciplinák alakulnak ki a természettudományokon belül, sőt természet-és társadalomtudományok között (például a környezet-tudomány).

A - maradjunk példánknál - települési területi egyenlőtlenségeket vizsgáló diszciplinák közül természetesen - tér-szintézise révén - a társadalomföldrajz áll a 
legközelebb a regionális tudományhoz. A vitacikk jellegéböl következik, hogy én a különbségek igazolására fektettem a hangsúlyt. A regionális tudományé a teljes (geográfiai, szociológiai, igazgatástudományi, közgazdasági stb.) tér-integráció szerepe. Ez az egyes diszciplinák eredményeiből állítható őssze. A regionális tudomány eredményei kitüntetetten több-szakmájú team-ekhez, vagy a különbözö diszciplinákban elért eredményeket egységes tér-koncepciókba elrendezni, integrálni tudó, a saját diszciplináris eredményeihez a más diszciplinákban elért eredményeket illeszteni képes kutatókhoz köthetók.

\section{Irodalom}

Berényi I. (2004) A funkcionális tér szociálgeográfiai elemzése. Földrajzi Tanulmányok 23. MTA Földrajztudományi Kutatóintézet, Budapest. 
Tér és Társadalom 21. évf. 2007/2. 133-136. p.

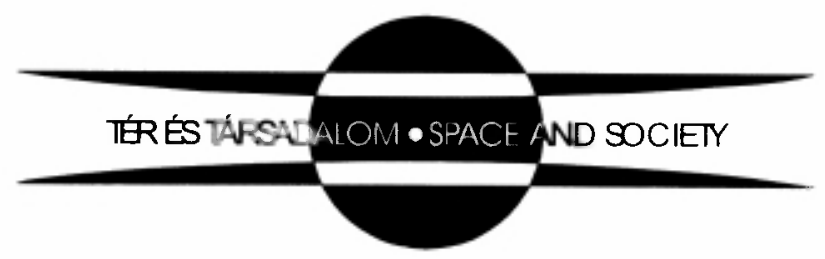

